Chicago-Kent College of Law

Scholarly Commons @ IIT Chicago-Kent College of Law

January 2012

\title{
Regionalization, Development and Competition Law: Exploring the Political Dimension
}

David J. Gerber

IIT Chicago-Kent College of Law, dgerber@kentlaw.iit.edu

Follow this and additional works at: https://scholarship.kentlaw.iit.edu/fac_schol

Part of the Antitrust and Trade Regulation Commons, Comparative and Foreign Law Commons, International Economics Commons, and the Law and Politics Commons

\section{Recommended Citation}

David J. Gerber, Regionalization, Development and Competition Law: Exploring the Political Dimension, (2012).

Available at: https://scholarship.kentlaw.iit.edu/fac_schol/246

This Contribution to Book is brought to you for free and open access by the Faculty Scholarship at Scholarly Commons @ IIT Chicago-Kent College of Law. It has been accepted for inclusion in All Faculty Scholarship by an authorized administrator of Scholarly Commons @ IIT Chicago-Kent College of Law. For more information, please contact jwenger@kentlaw.iit.edu, ebarney@kentlaw.iit.edu. 


\section{Competition Policy and Regional Integration in Developing Countries}

Edited by

Josef Drexl

Director; Max Planck Institute for Intellectual Property and Competition Law, Munich, Germany

Mor Bakhoum

Senior Research Fellow, Max Planck Institute for Intellectual Property and Competition Law, Munich, Germany

Eleanor M. Fox

Walter J. Derenberg Professor of Trade Regulation, New York University School of Law, USA

Michal S. Gal

Professor of Law, University of Haifa School of Law, Israel

\section{David J. Gerber}

Distinguished Professor of Law, Chicago-Kent College of Law, Illinois Institute of Technology, USA

\section{Edward Elgar}

Cheltenham, UK • Northampton, MA, USA 
All rights reserved. No part of this publication may be reproduced, stored in a retrieval system or transmitted in any form or by any means, electronic, mechanical or photocopying, recording, or otherwise without the prior permission of the publisher.

Published by

Edward Elgar Publishing Limited

The Lypiatts

15 Lansdown Road

Cheltenham

Glos GL50 2JA

UK

Edward Elgar Publishing, Inc.

William Pratt House

9 Dewey Court

Northampton

Massachusetts 01060

USA

A catalogue record for this book

is available from the British Library

Library of Congress Control Number: 2012935326

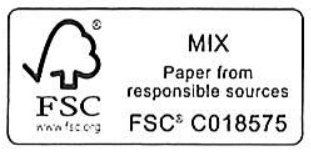

ISBN 9781781004302

Typeset by Columns Design XML Ltd, Reading

Printed and bound by MPG Books Group, UK 


\section{Regionalization, development and competition law: exploring the political dimension}

\section{David J. Gerber}

\section{INTRODUCTION}

In discussions of the regionalization of competition law, the political dimension often leads a shadowy existence. Regionalization tends to be presented with a hint of a halo around it. States are presented as acting for a shared policy objective intended to benefit all, and political issues often sit uncomfortably with that image. This is particularly true when regionalization involves 'developing countries'. Here there is often a further level of 'common good' discourse. Regionalization is here portrayed not only as a communal experience and goal, but also as one designed to reduce poverty and aid economic development. Where regionalization involves competition law, an additional veil often lies across the discussions. Competition law is about economics, it is said, and it serves the economic gains of the participating countries. This tends to distance the enterprise from any political factors. Each of these forms of discussion emphasizes safe, sanitized language and imagery.

Yet few would actually argue that the political dimension is not central to the process of regionalization. A key issue, then, is how to view, analyse and discuss the political dimension that everyone knows exists, but that many find awkward or unpleasant to talk about. Finding a language for discussing the political dimension thus takes on a central role.

In this chapter, some of the elements and factors that may be relevant to such an effort are sketched. The focus is on the regionalization of competition law in so-called developing countries, but the analysis is intended to be applicable to the regionalization of competition law in other contexts as well. Moreover, although the focus here is on the 'political' dimension in the regionalization of competition law, in my view a similar analytical 
approach can be usefully applied to other dimensions of the regionalization process as well.

With its origins in a symposium on the regionalization of competition law in developing countries, this chapter refers primarily to issues raised at the symposium and to regionalization contexts discussed there. ${ }^{1}$ It also goes beyond that material, however, and sketches some tools that can be used in analysing it.

Three basic objectives shape the chapter. One is to outline some conceptual tools that may be useful in analysing this new set of issues. In my experience, these issues are typically discussed in very loose terms that tend to obscure rather than to enhance insights into the dynamics of regionalization. A second goal is to locate political elements at two key points in the regionalization picture - that is the impetus for regionalization and the process of competition law implementation. The third is to assess some of the consequences of this process.

The investigation revolves around two principal themes. One is the centrality of the political dimension in the process of regionalizing competition law, perhaps especially in the context of developing countries. Although seldom addressed in more than a perfunctory way, it is critical to understanding the regionalization phenomenon as well as generating insightful analysis of its implications. The other is the intertwining of economic language and political dynamics. Discussions of this issue tend to focus on its economic dimension, but the political dimension is typically, perhaps always, interwoven with the economic dimension, and it is this relationship that must be at the centre of effective analysis.

The chapter first identifies what I mean by the 'political dimension' and sketches a way of analysing it that I believe has analytical value. It then looks at the political dimension in two contexts involving the regionalization of competition law, and asks how the impetus to regionalize competition law is shaped and how this then affects the implementation of competition law. Finally some implications of this analysis are identified.

Before I examine these issues, however, it is necessary to clarify some issues of scope. First, the chapter uses the term 'regionalization', but it is important to recognize that the term is highly contingent. The dynamics of a specific instance of regionalization depend on many factors - for example, the number of countries involved in the process, their geographical location, the wealth and economic and social characteristics of the participants, as

1 Many of these issues are also included in the symposium volume of which this chapter is a part. 
well as the economic and power relationships within the group, and so on. The term is used here in an abstract and general sense, but it is important to keep these factors in mind. The original symposium focused on regionalization in the context of economic development, with many participants from Africa, and thus these experiences were naturally in the forefront of the contributors' thinking about the subject, even when they are not specifically addressed. Second, the term 'competition law' refers to laws whose function is to combat restraints on competition. In some countries, notably the United States, the term 'antitrust law' is used to refer to this type of law. Note also that the term 'competition law' is used more broadly in some legal systems, where it may refer to 'unfair competition law', that is, law designed to protect competitors from unfair conduct by other competitors. Third, my concern here is with regionalization in the so-called developing world. In particular, I do not include here issues of regionalization in Europe. ${ }^{2}$

\section{IDENTIFYING THE POLITICAL DIMENSION}

As noted above, one objective of this chapter is to develop ways of analysing the regionalization of law, in particular the regionalization of competition law in developing countries. The loose language typically used to refer to this process tends to obscure the value of analysing its components carefully. In my view, this is an obstacle to effective analysis and decision making, and thus I provide here the lines of analysis that I use for this chapter.

The analysis starts from the basic proposition that regionalization is a process - a set of interactions over time among an identifiable set of participants. Although obvious at one level, this process perspective is seldom given much attention, and few focus on it in analysing the phenomenon with which this chapter is concerned. However, this process perspective is central to this analysis.

Using this starting point, I need to specify the scope and contents of the process. Here I am concerned with a specific process, that is, the process of

2 Many of the issues and problems faced by developing countries in their efforts to regionalize competition law were also faced by European countries in the process of European integration. Some of those problems remain, but the process of European integration has altered them, often fundamentally. Moreover, developing countries often face additional problems in this area that Europeans have not faced. A comparative analysis of these issues could be very valuable, but it is beyond the scope of this chapter. 
regionalizing competition law. The process consists then of the interactions over time related to development of a competition law that is applicable throughout a geographical region. It is thus defined geographically by reference to a region. It is also defined by reference to its content. It refers to interactions that relate, inter alia, to the creation and operation of a competition law system - its norms, its institutions and its procedures.

Penetrating further into the process, the chapter asks what its basic elements are. This question leads to a focus on decisions as the components of the process. ${ }^{3}$ Viewed together, the decisions taken in relation to the regionalizing competition law constitute the process. The term 'decision' can be misleading, because in discussions of law it is typically used to refer to formal decisions such as those of courts or administrative authorities. Here, however, the concept is broader. I use 'decision' to refer to any decision by any actor that is part of the process of developing competition law. It includes, therefore, formal decisions of institutions, for example the enactment of a national statue permitting the government to transfer some of its authority to regional institutions. It may also include, however, many other decisions, for example decisions by actors (decision makers and those they influence) in one set of institutions to talk with actors in another state about the regionalization process.

Decisions are, however, products. They are always shaped by a variety of factors, and it is these factors that thus provide access to understanding decisions and permit analysis of their significance in relation to the regionalization process. They must, therefore, also be taken into account in analysing the process. The actual decision is just a kind of temporary stopping point at which decisional influences interact.

These decisional influences take a variety of forms. In some contexts, they relate to a text, for example an agreement that creates obligations on a regional level. Institutions that are involved with the regionalization process - whether national, regional or supra-regional - represent a second category of influence. Communities - status relationships, contacts, networks, etc. provide a third form of decisional influence. For example, where a group of economic officials or scholars or business leaders perceives the value of competition law, the relationships within the group can be an important form of support for competition law development. Shared perceptions of the potential harms from regionalizing competition law may also, of course,

3 For fuller discussion of this perspective, see Gerber, D.J. (1998), 'System Dynamics: Toward a Language of Comparative Law', 46 American Journal of Comparative Law 719-37. 
create or support opposition to such a project. Finally, patterns of thought values, perceptions, etc. - represent another form of influence that may or may not be tied to the other forms of influence just noted, that is, institutions, communities and texts.

The term 'political' is often used very loosely in discussions of regionalization (and in legal discussions involving international issues generally). It is important, therefore, to specify how the term is used here. For our purposes, the term 'political' refers to decisions that are associated with the acquisition, maintenance or exercise of political authority. This definition includes factors that are normally considered political, such as efforts to maintain power in a particular political system, but it also includes the use of that power in an international context. For example, when officials of the United States government seek to influence a foreign government in decisions about competition law, this is also a political influence, because they represent the political institution that is the US government.

The concept of 'association with' is used here to describe the boundaries of the inquiry - that is, it identifies the kinds of influences that will be considered as 'political'. I use the term 'association' in a relatively broad sense, but for our purposes the lack of precision regarding its borders does not create significant problems. Its function is to identify those factors that influence decisions related to competition law, and these factors can vary along numerous lines. The decisions may themselves be based on or authorized by political authority, but they may also be influenced by factors such as the personal or institutional interests of the decision makers or by cognitive factors such as the perception of competition law's potential value. The fact that the boundaries of the category are not always clear does not, therefore, diminish the value of the term. In any event, this focus on decisions and decisional influences enables a more precise analysis of the political dimension.

Influences on these decisions can come from three basic levels. One is national. National institutions or groups will necessarily be important influences on decisions by national authorities. Regional institutions or groups are a second level of influence. In most of the developing world, these institutions and groups remain relatively weak, and they are seldom well supported. This is not always the case, however, and regionalization as a project typically reflects an interest in further developing them. Finally, influences may derive from outside the region. They can be called 'supraregional' influences; for example, international institutions may have such influence, and foreign governments often play such a role. 
This analysis is briefly applied to two key elements of the process of regionalization of competition law. One includes decisions related to the formal regionalization of competition law - that is, the impetus to locate competition law at the regional level. This represents a formal transfer of authority for competition law issues to the regional level. It says nothing about how that authority is used. The other element of the process relates, then, to the actual implementation of competition on a regional level. In each case, I examine the location of the decisions, the sources of influences on those decisions and the forms of influence. Thus it is shown that the influences are aligned very differently in these two domains.

\section{THE IMPETUS TO LOCATE COMPETITION LAW AT THE REGIONAL LEVEL}

The central question in the regionalization of competition law is whether to do it, so the analysis above is first applied to this set of decisions. The decisions involved are identified as well as the types of influences to which they may be subjected. The analysis suggests that the potential for significant support of competition law regionalization among developing countries may be quite high, and examples of this kind of support can increasingly be found in developing countries, most notably in Africa. ${ }^{4}$ It is important to remember that many such countries do not have national competition laws or, if they have them, they are minimally enforced. ${ }^{5}$

Regionalization can take many forms, but for the purposes of this analysis, I use the term to refer to formal decisions to locate competition law norms at the regional level and to rest primary responsibility for enforcement at the regional level. These are the elements that appear to be commonly assumed in discussions of the regionalization of competition law.

The decision to regionalize competition law is the prerogative of national decision makers - that is, it is located on the national level. At least in the developing world, states have generally not ceded the power to regional

4 Numerous contributions in this volume document this support in Africa. See, e.g., Lipimile, G.K., 'The COMESA Regional Competition Regulations', in this volume, Ch. 10.

5 The leading analysis of competition law issues in small market economies is Gal, M. (2003), Competition Policy for Small Market Economies, Cambridge, MA: Harvard University Press. For discussion of experience with these issues see Gerber, D.J. (2010), Global Competition: Law, Markets and Globalization, Oxford: Oxford University Press, pp. 236-58. 
organizations to make such decisions on their own authority. The task then is to identify influences on national decision makers to transfer political authority to regional institutions to this extent and for these purposes. Although the decisions are located at the national level, influences on those decisions may come from national, regional or global levels.

\subsection{Domestic (National-level) Influences}

On the domestic level, the influences revolve around the fact that political decision makers typically focus their attention on achieving and/or maintaining domestic support for themselves and their actions. In other words, the decisions are political in the sense used here - that is, they relate to the acquisition and maintenance of political authority. The question then is whether regionalization of competition law is perceived as a significant benefit by national-level decision makers and, if so, to what extent. To the extent that it is perceived to bring greater benefits than costs, this represents an incentive to regionalize. Of course, there are disincentives to regionalize when the benefits do not outweigh the costs. 'Benefit' here refers not only to perceived benefits to the 'common good', but also to personal benefits. These may take many forms - from straightforward payments to public officials to more subtle benefits related to the power, status or resources of the decision makers.

I distinguish here between two forms of influence. For the purposes of this argument, 'process factors' include those that are related to participation in the process of locating competition law at the regional level. Here the issue is not what benefits or harms are produced by the process, but rather what benefits or harms are produced by participating in it. In contrast, 'product factors' include those related to the results or consequences of the process - that is, what the process produces. This chapter identifies some of those that were most prominent at the symposium and in the subsequent discussions of these issues.

\subsubsection{Process factors}

Process factors can provide significant incentives for developing countries to regionalize competition law. Here the focus is, as noted, on the benefits and costs of creating and participating in the process of regionalizing competition law.

3.1.1.1 Incentives Among the more prominent incentives is the desire to shift cost and responsibility from the national level to the regional level. A 
national competition-law, system is likely to be expensive for a small country, especially if it actually intends to implement the law. Developing countries, by definition, are thin on public resources, at least those devoted to public benefit. Moreover, they are often small. They typically, therefore, do not have significant resources to support competition law. There is an attraction, therefore, in merely shifting responsibility for competition law to the regional level. ${ }^{6}$

This shift is also likely to have a related benefit - it can deflect nationallevel resistance to competition law from national officials and politicians to regional-level institutions and decision makers. Competition law inevitably creates resistance from many business leaders, who fear that it will limit their potential range of competitive strategies and impose compliance costs. This is especially likely when competition law is new and its potential benefits are difficult to perceive. This is typically the case in developing countries. When, however, business decision makers perceive the potential benefits of competition law, these perceived benefits can counterbalance such concerns. This may be the case, for example, when they have recognized and understood the potential of competition law to support economic growth in the country or when they have recognized that it might help to protect them against larger and more technologically advanced 'western' firms.

Another incentive to regionalize competition law relates to pressures from foreign or international sources. When competition laws may impact a foreign firm, that firm and its representatives are likely to resist the application of these laws by putting pressure on the competition authorities and others in government. This can be a cost to domestic officials (although it can also be a source of remuneration for them). If the responsibility for enforcement is transferred to the regional level, such pressures will be diffused and tend to be less of a burden on national officials and politicians.

A regionalized competition law can also be expected to have a stronger voice internationally than the voice of a single, developing country, especially if the country is small or has limited economic leverage. In the context of globalization, therefore, there may be significant incentives for

6 For in-depth analysis of these issues, see Bakhoum, M. (2007), L'articulation du droit communautaire et des droits nationaux de le concurrence dans l'Union Economique et Monétaire Ouest Africaine (UEMOA), Bruylant: Stämpfli, Berne. A shorter English version is in Bakhoum, M. (2006), 'Delimitation and Exercise of Competence Between West African Economic and Monetary Union (WAEMU) and its Member States in Competition Policy', 29 World Competition 674. 
such countries to regionalize in order to strengthen their collective voice, thereby also enhancing the status and possibly the geopolitical power of the countries in the region. ${ }^{7}$

The regionalization of competition law may also create incentives related to influence and power relationships within the region. It may allow some countries to extend their power and influence. Larger, more economically or politically powerful countries tend to have correspondingly more influence within regional organizations. The regionalization of competition law can be used as a means of extending countries' reach throughout the region through influencing the rules for competition in the area. The capacity to extend influence in this type of context depends, of course, on specific situations of regionalization, but the examples of the West African Economic and Monetary Union (WAEMU) and the Central African Economic and Monetary Community (CEMAC) indicate the potential role of these issues. ${ }^{8}$

\subsubsection{Disincentives Disincentives related to the process of regionali-} zation often centre on the loss of control over a state's markets. Competition law seeks to establish the parameters of competitive conduct in a market; control of the rules of competition at the national level can have significant value for many in the country, among both government officials and businesses. When competition law is regionalized, domestic capacity to influence these rules of competition is shifted to the regional level. This reduces the influence not only of national governments, but also of those who are able to influence domestic decisions at the national level but may have less influence on regional decision makers. In such situations, the only way to influence the rules of competitive conduct in one's own market is to influence decisions at the regional level, and this may be far more difficult and costly than influencing decisions in a domestic system.

A related issue involves the potential 'interference' of regional institutions within domestic economic and possibly political life. Where the

7 These issues are important, e.g., in efforts in the Caribbean to develop regional competition law. For discussion, see the contribution by Stewart, T., 'Regional Integration in the Caribbean: The Role of Competition Policy', in this volume, Ch 8.

8 For discussion, see, e.g., Boy, L. and L. Boumsong, comments on the competition law of CEMAC, workshop on 'Regional Integration and Competition Law in Developing Countries', unedited. Also, Bakhoum, M. and J. Molestina, 'Institutional Coherence and Effectiveness of a Regional Competition Policy: The Case of the West African Economic and Monetary Union (WAEMU)', in this volume, Ch 5. 
rules for competition are set and enforced by regional institutions, a state and its stakeholders not only lose control, but they also run an increased risk of interference with domestic business. In a regional context in which there is a lack of trust among members, each may also fear that 'regional decisions' are in fact being influenced by their economic and/or political competitors.

Finally, the lack of perceived equality among members in the regionalization process can be a significant disincentive to regionalization. The benefits and costs of a competition law regime are often difficult to assess, much less effectively apportion among members. 'Why should we pay for protection of their market?' might well be a response to many situations. At the very least, there is significant potential for conflict and uncertainty in the apportionment of costs and the evaluation of benefits.

\subsubsection{Product factors}

Product factors are those that relate to what regionalization is expected to produce - that is, the economic or other results that can be expected from it. Here the assumption is that competition law will produce positive results. Expectations of such results can be significant factors in a state's decision to agree to regionalizing competition law. These expectations are, however, necessarily vague and uncertain. The history of regionalizing competition law in developing countries has yet to demonstrate clear product results, and expectations of product are, therefore, based on assumptions and even aspirations.

One 'product' is an expected increase in the effectiveness of competition law. Support for regionalizing competition law generally assumes that competition law at the regional level is likely to be more effective than domestic-level competition law in combating restrains on competition. One basis for expecting such an increase in effectiveness is that regionalization allows the pooling of resources, especially financial and knowledge resources. Decision makers in developing countries are typically aware that the lack of resources hampers the effectiveness of the laws they promulgate, and thus this resource enhancement is likely to be a paramount objective. In addition, regionalization can be expected to increase effectiveness by reducing opportunities for foreign firms to avoid competition law constraints by playing one country off against others in the region. In this scenario, dominant firms can often expect to get a better deal in relation to competition law in one country in the region by threatening to move their 
operations to a neighbouring country. This was apparently an impetus for regionalization in southern Africa. ${ }^{9}$

In addition to increased effectiveness of competition law, it is often assumed that competition law at the regional level will be more efficient that is, it will not only be more effective than national-level competition laws, but its costs will be lower in relation to its product. For example, in a region of small, developing countries such as West Africa, regionalization can be expected to reduce costs and increase efficiency in the elaboration and implementation of competition law.

Given that these expectations are based on little more than assumptions, however, those who make different assumptions are likely to arrive at different expectations. For many, there is little reason to suppose that competition law will be more effective at the regional level than it is at the national level or that it will be less costly in relation to the benefits it produces. Others are more optimistic about this prospect.

\subsection{Regional-level Influences}

Regional-level influences on domestic decisions to regionalize competition law are likely to be limited, except in those relatively rare situations in which regional institutions have been set up without including competition law and those institutions have achieved significant status and credibility throughout the region. In such situations, regional institutions are likely to encourage competition law to be added to the capacities and tools available to the regional organization. Where a regional organization is established, its goals are typically to increase economic integration and/or improve intra-regional trade. Competition law is often portrayed as a tool for supporting these goals, and this is likely to lead regional institutions to seek to transfer it to the regional level.

In the more common situation, the regionalization of competition law is presented as part of the general 'package' of issues attending the question of whether to establish a regional organization. Here the issue is whether to include competition law in the regionalization package, and decisional influences at the regional level will thus derive from non-institutional sources. For example, perceptions of the value of including competition law in a regionalization package may be shared across a region, thus providing a

9 See, e.g., the contribution of Mamhare, G., 'Southern African Development Community (SADC) Regional Competition Policy', in this volume, Ch. 3. 
means for mutual reinforcement of support for including competition law as part of the general plans for regionalization.

\subsection{Extra-regional Influences}

Governments in countries outside the region also influence national-level decisions regarding the regionalization of competition law. Competition law can significantly impact the incentives to invest in a region and the costs of doing business there. As a consequence, countries whose businesses might be involved in transactions or operations in the region have an interest in whether competition law will be regionalized. For example, a foreign government may wish to have greater uniformity of competition law in the region or it may wish to have competition issues centralized at the regional level so there are fewer key decision makers. This reduces the number of officials with whom it may have to negotiate, and it may increase the capacity of the foreign government to influence them. Extra-regional government officials may also be interested for a different set of reasons. Officials may, for example, wish to spread their own influence, and the influence of their own institutions, by exporting their own version of competition law to an entire region. ${ }^{10}$ The US, the European Union, Japan and other countries have made significant efforts to influence competition law development for reasons including these. In general, these countries have encouraged competition law, but they have, of course, encouraged their own forms of competition law. ${ }^{11}$

Extra-regional businesses may perceive similar benefits in regionalization. Creating greater uniformity in the rules applicable in an area and reducing the number of decision makers enforcing them can be a significant factor in assessing the profitability of investment and transactions in the area. Reducing disparities in the legal framework applicable within the region in and of itself reduces planning and compliance costs and increases predictability in planning. Moreover, it reduces the number of institutions and decision makers that may impact business decisions. This becomes especially clear when payments and favours to competition officials may be required in order to secure favourable decisions.

International organizations also represent extra-regional influences, and they tend to push in the same direction as the capital-exporting countries

10 For discussion of such efforts by the US and EU, see, e.g., Gerber, D. supra note 5 , at $236-58$.

11 For discussion of US efforts along these lines, see, e.g., ibid. at 156-7. 
mentioned above. The International Competition Network (ICN) is a virtual organization that encourages discussions among competition law officials (and, in practice, others such as practitioners and even professors). ${ }^{12}$ One of its goals is to establish 'best practices' in competition law that many countries will follow. Standardizing competition law at the regional level tends to foster this agenda. Given that in practice the organization tends to be strongly influenced by officials from the US and Europe, it also tends to favour competition law practices that follow the general outlines of competition law in those legal systems.

Two other organizations play important roles in this context. ${ }^{13}$ The Organisation for Economic Cooperation and Development (OECD) is an organization of member governments that have achieved specified levels of economic development. It represents a kind of club for the 'developed countries', and thus membership represents status on the global level, which in turn creates incentives for countries to become and remain members. The OECD has generally encouraged competition law development and harmonization among its members, and in recent years it has paid increasing attention to encouraging and harmonizing competition law in non-member countries. The United Nations Conference on Trade and Development (UNCTAD) has long encouraged and supported competition law development in developing countries, and in recent years it has supported efforts to regionalize competition law. Both institutions thus support decisions to regionalize competition law.

This brief look at decisional influences relating to the regionalization of competition law reveals significant incentives to regionalize competition law and limited disincentives. This formal first step can have many consequences. It is obviously a necessary first step towards creating a regional competition law that is actually effective and influential. Moreover, it can support the general effort to increase regional integration. Nevertheless, until and unless there is implementation, its impact will be limited. When

12 For analysis of the ICN and its roles, see Fox, E.M. (2009), 'Antitrust and the Virtues of a Virtual Network', 43 Intl Lawyer 151-74.

13 The World Trade Organization does not directly deal with competition law, but it generally encourages market-based reforms for developing countries. There have been efforts to include competition law in the WTO, and many believe that these issues will eventually be included in some form in the WTO. For discussion of previous efforts to include competition law in the WTO, especially its relationship to economic development, see Drexl, J. (2004), 'International Competition Policy After Cancún: Placing a Singapore Issue on the WTO Development Agenda', 27 World Competition 419-57. 
we look at costs and incentives at the implementation stage, however, the incentives actually to implement competition law may be far more limited.

\section{IMPLEMENTING REGIONAL COMPETITION LAWS}

The last section looked at the impetus to regionalize competition law. Here, some of the factors that relate to implementing competition law on a regional level are examined. The issue of whether and to what extent competition norms will actually have effect and whether the procedures put in place will actually be utilized is historically and theoretically different from the decision to establish formal regionalization of competition law. In particular, analysis of the political dimension reveals far less support for implementation at the regional level than it did for formal regionalization. Here again, the political elements tend to be underemphasized in many discussions of the subject, despite the obvious and fundamental point that competition law requires political support for its implementation.

Notice that the issue here is 'implementation' - the decisions taken to achieve the objectives of the law. This is normally equated with 'enforcement', and I will follow that practice in this chapter - that is, focusing only on implementation through enforcement. There are other tools for achieving the objectives of competition law, however, and a fuller analysis would examine them as well. In particular, education has been critical in the development of competition law in most countries and areas. Competition law is not an area of law that is easily understood. Especially when decision makers and political stakeholders have limited experience with the process of economic competition itself, and/or have limited confidence in state institutions, history suggests that education may be a critically important form of implementation. ${ }^{14}$

Recall also that for the purposes of this chapter it is assumed that enforcement occurs primarily at the regional level. There are a variety of ways of sharing enforcement responsibility with national-level authorities. In Europe, for example, primary enforcement of regional competition law was transferred to national-level authorities in 2004 , although the principles

14 For discussion of the role of education in developing competition law in Germany, see Gerber, D.J. (2001), Law and Competition in Twentieth Century Europe: Protecting Prometheus, Oxford: Oxford University Press, pp. 270-96. 
and practices of enforcement remain closely controlled by Brussels. ${ }^{15}$ In any event, space limitations preclude an investigation of these varieties here.

\subsection{National-level Influences}

Domestic political influences on regional-level decisions are subject to many variables. My objective here is merely to identify some of the factors that experience has shown to be relevant, or that decisional analysis predicts are likely to be relevant. I look here at the groups that may influence regional-level decision making and at some of the factors that shape that influence. It is worth emphasizing that regional-level institutions can be expected to be highly responsive to national-level pressures, perhaps especially in developing countries.

National-level influence on regional implementation decisions can be expected from four main sources. One is the government officials and institutions charged with competition law issues. This refers primarily to officials of the national competition law authority where one exists, but there are typically others in the government who have responsibility for competition issues, whether or not a competition authority actually exists. When competition law is regionalized, these national-level institutions and responsibilities are likely to remain. These officials are likely to know and interact with regional-level officials and to seek influence with them. For national officials, regional implementation can be expected to represent significant cross-cutting incentives. On the one hand, competition law officials, whether for personal or policy reasons, have incentives to increase their power and influence, and regional implementation may run counter to those objectives. On the other hand, as noted above, effective implementation at the regional level may increase the effectiveness of competition law norms and thereby foster their institutional objectives.

A second category includes other government officials who can be expected to have significant interest in implementation at the regional level. For example, the ministry of commerce is likely to put pressure on the regional authority not to harm the interests of its nationals or businesses. At the same time, the ministry presumably also has incentives to support the goals that regionalization presents. These officials thus also have crosscutting incentives that may inhibit strong support for regional implementation efforts.

15 For discussion, see Gerber, D.J., supra note 5, at 187-204. 
National business leaders represent a third group who are likely to have significant incentives to influence competition law enforcement at the regional level. In general, businesses resist competition law enforcement, especially when it affects their own interests. Where enforcement is national, such leaders can often bring significant pressure to bear on national officials not to harm their interests. Where enforcement is regional, their interest in deterring it remains, but now they have the additional concern that some other group or government within the region may have greater influence on regional enforcement than they have and will use it to their own advantage. This is likely to lead to even greater scepticism and resistance to enforcement.

Finally, domestic professional groups may be particularly concerned with implementation. Lawyers, accountants and others are likely to have predominantly or exclusively domestic clients, and part of their value to their clients typically rests on their connections to local officials. Where implementation decisions are taken at the regional level, these nationallevel contacts diminish in value. This may be offset by other factors such as an increase in enforcement activity, but that effect is hard to predict, whereas the potential loss of influence by moving implementation to the regional level is obvious.

In each of these cases, therefore, national-level political influences are likely to impede enforcement at the regional level.

\subsection{Regional-level Influences}

Regional-level influences obviously become greater and more diverse when competition law becomes part of a regional organization. The regional institutions themselves and the interests associated with them now become sources of influence. In principle, these institutions can be expected to foster and support implementation of competition law at the regional level. Regional-level enforcement can enhance the effectiveness of other regional policies such as trade liberalization, and it can thereby strengthen regional institutions.

There are also, however, numerous disincentives for regional officials to engage in significant competition law enforcement. First, competition law is now part of the budget. The costs of implementation are now to be paid at the regional level, so that budgetary considerations become a factor, and, given the potential cost of significant enforcement, this factor can be significant. This is not only, or even primarily, a financial issue. Apportioning these costs among member states is often a highly sensitive political 
issue, especially in the early stages of regional integration, when the regional institutions are not well established and/or have not yet generated significant trust in their decisions.

Second, enforcement necessarily also engenders conflicts at the regional level. Questions such as 'who is enforcing against whom and for whose benefit?' are brought to the fore. Third, regional institutions are typically trade-promoting institutions. Their primary objective is to reduce barriers to trade between the countries of the region. While competition law supports this objective, its enforcement can increase conflicts and tensions within the regional bloc and make progress in trade negotiations more difficult. Experience confirms the influence of these types of factors. ${ }^{16}$ There is little evidence as yet that regional organizations have paid great attention to enforcement of competition law.

\subsection{The Extra-regional Level}

Finally, the line-up of decisional influences at the extra-regional level changes, and again these influences tend to provide far less support for enforcement at the regional level than they do for formal regionalization of competition law.

International institutions generally have less influence on competition law enforcement than on the formal regionalization decision itself - that is, there is often significantly more attention paid to the establishment of a competition law system than to what it actually does. The ICN, for example, is not in a position to provide significant support for enforcement efforts. It is a voluntary organization that itself has no officials and no means of even monitoring enforcement efforts. This does not mean that it ignores enforcement issues. It does discuss enforcement issues and policies, and it seeks 'best practices' in these areas. These can be helpful as reference points for local administrators in convincing others that the practices should be followed at the regional level, but this type of influence is indirect and somewhat conjectural, depending, for example, on domestic views of the ICN mechanisms themselves. The ICN also has few incentives to do more

16 For discussion of experience in this context in West Africa, see, e.g., Bakhoum, supra note 5, and the contributions of Bakhoum/Molestina and M. Ngom in this volume, Chs 5 and 6 . For analysis of the reasons for lack of implementation in the Andean Pact context, see the contribution by Cortázar, J., 'Andean Competition Law: Looking for the Private Sector, or the Quest for the Missing Link in Antitrust', in this volume, Ch. 7. 
than recommend best practices. It registers institutional successes when policies are formally adopted, but as a virtual organization its concerns cannot be expected to go far beyond that.

The OECD's efforts with regard to competition law enforcement have concentrated on its member states. Here enforcement issues are investigated, and the organization does support enforcement efforts. As noted, however, its members do not include developing countries. Its efforts in relation to such non-member states have generally focused on encouraging the introduction of competition law and on the analytical issues involved in establishing a competition law, but the organization has limited incentives to try to deal with implementation issues among member states, and it has limited leverage to encourage non-member states to follow its enforcementlevel suggestions.

UNCTAD is the organization that has been most concerned with competition law enforcement in developing countries, and it has supported regional integration efforts in important ways. The UNCTAD staff travels widely in developing countries to monitor and develop enforcement efforts, and it regularly employs independent experts to investigate these issues. Especially in recent years, its activities at this level have been energetic and influential. Nevertheless, the organization has limited leverage in encouraging enforcement. It does not control access to significant amounts of resources or to status, and it does not have a well-developed means of prodding domestic or regional institutions to enforce competition law provisions.

The analysis in this section suggests that support for enforcement at the regional level may be limited, at least initially. It requires both support for competition law as a normative component of economic life and support for regional institutions. Yet in the context of developing countries, these requirements are not likely to be easily met. Competition law is seldom well known in developing countries, and experience suggests that significant time may be necessary for it to be widely understood and supported. Similarly, experience in the context of European integration and elsewhere suggests that support for regional institutions is likely to develop slowly at best. As a result, at least in the early stages of regionalization, support for competition law enforcement at the regional level is likely to face significant obstacles. 


\section{CONCLUDING COMMENTS}

This review of the political dimension in the regionalization of competition law in developing countries reveals two very different vectors of incentives and decisional influences. On the one hand, decisional influences relating to political authority tend to support formal regionalization. There are many incentives formally to regionalize competition law, and the costs of formal regionalization tend to be limited. On the other hand, however, political factors provide far less support for implementation of competition law at the regional level. There the costs are higher and the political benefits more limited.

This analysis has many implications for plans to regionalize competition law in developing countries. Among the most important is the awareness that there is likely to be a very significant gap between the formal establishment of competition law as part of a regionalization effort and the actual enforcement of that law. Officials, politicians and other decision makers have conflicting incentives that are likely to lead them to talk about regionalization as a positive step, but to act in ways that are inconsistent with significant enforcement. I refer to this as bi-level conduct - one form of discourse and action that is directed towards global and regional communities, but decisions about enforcement that focus on local needs and political relationships.

A second implication is that competition policy at the regional level should take these cross-cutting influences into account. This suggests, for example, that expectations for immediate enforcement efforts should be low. As we have seen, there are many obstacles to achieving significant enforcement. A longer-term perspective on regionalization fits far better with the incentive structure. In such a perspective other forms of implementation such as education may take centre stage initially, and actual enforcement may be viewed as a longer-term objective for which education provides the foundation.

Our analysis has pointed both to the importance of analysing the political dimension of regionalizing competition law and to some of the difficulties in addressing these issues. There are many reasons for the frequent reluctance to talk about the political dimension and to focus discussion instead on the economic aspects of such regionalization. One is that the political dimension is often perceived to be in tension with the basic goals and justifications of regionalization. At another level, however, the discussion is hampered by the lack of a language in which the political dimension can be analysed and discussed effectively. 
This chapter sketches the outlines of such a language - that is, a language that effectively analyses the political dimension in the regionalization of competition law. It has two key components. One is an emphasis on the value of a 'systemic' perspective that identifies interactions and influences between national institutions, interests and perspectives, on the one hand, and regional interests and objectives, on the other hand. Globalization dynamics are also integrated into this regional analysis. The other key component is the use of the concept of 'decisions' as a means of analysing the interplay among these system-based elements and systemic relationships. 